\title{
ORGANIC GEOCHEMISTRY OF PALEOCENE - MIDDLE MIOCENE SUCCESSION, EE85-1A WELL, RAS BUDRAN, SUEZ GULF, EGYPT
}

\author{
Khaled, K. A. M. and Edress, N. A. A. \\ Helwan University, Faculty of Science, Geology Department.
}

\begin{abstract}
Ras Budran area is located in the central eastern offshore area of the Suez Gulf. The sedimentary successions from the Paleocene to the Lower-Middle Miocene were chosen to assess in the well EE85-1A at the Ras Budran area.Thegeochemical analysis of the Rock-Eval and vitrinite reflectance was applied for evaluating the studied Formations from the viewpoints of the petroleum systems. From which fifty-four cutting samples represented six Formations of Esna Shale (Paleocene), Thebes (Lower-Middle Eocene), Darat (Upper Eocene), Nukhul, Rudeis (Lower Miocene), and Kareem (Lower-Middle Miocene) were analyzed. The present study distinguishes three different categories of petroleum source potential. The first is very good to excellent source of Thebes Formation has $3.2 \mathrm{wt}$, \% TOC and $22.1 \mathrm{mg} \mathrm{HC} / \mathrm{g}$ rock of Production yield $(\mathrm{Py}=\mathrm{S} 1+\mathrm{S} 2)$ on averages. The second is fair sources of the Nukhul, the Darat, and the Esna Shale Formations of averages 1.23, 1.6 and $0.85 \mathrm{wt}$, \% TOC and 1.67, 3.12 and $1.8 \mathrm{mg} \mathrm{HC} / \mathrm{g}$ rock of Production yield respectively. The third is a poor source of both the Kareem and the Rudeis Formations of averages 1.4 , and $0.95 \mathrm{wt}, \%$ TOC and 1.5 , and $0.92 \mathrm{mg} \mathrm{HC} / \mathrm{g}$ rock Py. The kerogen types of oil-prone (Type I) and mixed oil/gas prone (Type II) are the main OM (organic matter) constituent of the Thebes Formation of HI (hydrogen index) $>400 \mathrm{mg} \mathrm{HC} / \mathrm{g}$ TOC and S2/S3 ratio is $6.97 \mathrm{mg} \mathrm{HC} / \mathrm{g}$ rock on average. The results are categorized the Thebes Formation to be an effective source rock if buried enough to reach the oil window zone. The other Formations of Kareem, Rudeis, Nukhul, Darat, and Esna Shale include kerogens of gas prone (types III) and inert (Type IV) of HI (hydrogen index) $<200 \mathrm{mg} \mathrm{HC} / \mathrm{g} \mathrm{TOC}$ and $\mathrm{S} 2 / \mathrm{S} 3$ ratio $<2 \mathrm{mg} \mathrm{HC} / \mathrm{g}$ rock too.
\end{abstract}

Keywords: Organic geochemistry, Sea level cycles, Geothermal gradient, Vitrinite reflectance, Ras Budran, Suez Gulf, Egypt.

\section{INTRODUCTION}

The area of Ras Budran is situated among three main oil field concessions in the central Gulf; east of North October, northwest of October, and north Belayim concessions (Fig. 1). It lies nearly $4 \mathrm{~km}$ to $13 \mathrm{~km}$ from the western road connected the coastal cities of Abu Zenima and Abu Rudeis. The area lies north to numerous discovered oil fields in the central Gulf such as Sidri, Feiran, and Belayim Land and Belayim Marine. The wells EE85-1A has the coordinates of $33^{\circ} 07^{\prime} \mathrm{E}$ and $28^{\circ} 58^{\prime} \mathrm{N}$. It lies in shallow water depths of forty meter within the lower shore-face of the continental shelf bounded the present day eastern Gulf coast. The EE85-1A well reaches its total depth of $3829.5 \mathrm{~m}$ (12564 ft) penetrate the Rift-infill and preRift sequences until Nubia B (Upper Carboniferous). The well under investigation produces oil from five sedimentary intervals (reservoirs) of the Matulla, the upper and lower Raha, the Nubia A (Mallha) and the Nubia B (Rod El Hamal) Formations of pre-Rift sequence.

Since the nineteen century, The well EE85-1A drilled by Deminex was the first from many other exploratory offshore wells drilled by SUCO and GUPCO oil companies that draw the considered area to be a major oil field in the Gulf with an oil reserve reaches billion of the oil-barrels in place.

The stratigraphic successions of sedimentary strata within Ras Budran recognized as pre-Rift sequence (from the Cambrian to the Eocene) and Rift-infill sequence (from the Oligocene to the Recent) (Alsharhan and Salah, 1995). Many authors divided the span time of Rift-infill into syn-Rift (from the Oligocene to the Late Miocene) and post-Rift (from the Pliocene to the Recent) (Chowdhary and Taha, 1987;Darwish and El Araby, 1993; Darwish et al., 1998; Dolson et al., 2001).The Matulla and the Raha Formations of 
Khaled, K. A. M. and Edress, N. A. A.

the Upper Cretaceous andthe Nubia (A, B, C, and D) sandstone intervals from the Cambrian to the Lower Cretaceous are the main oil-bearing reservoirs in the studied area (Chowdhary et al., 1986; Alsharhan, 2003; Boukhary et al., 2012).

Fig. 1: Location map of the major petroleum province in the Suez Gulf (EGPC, 1996).

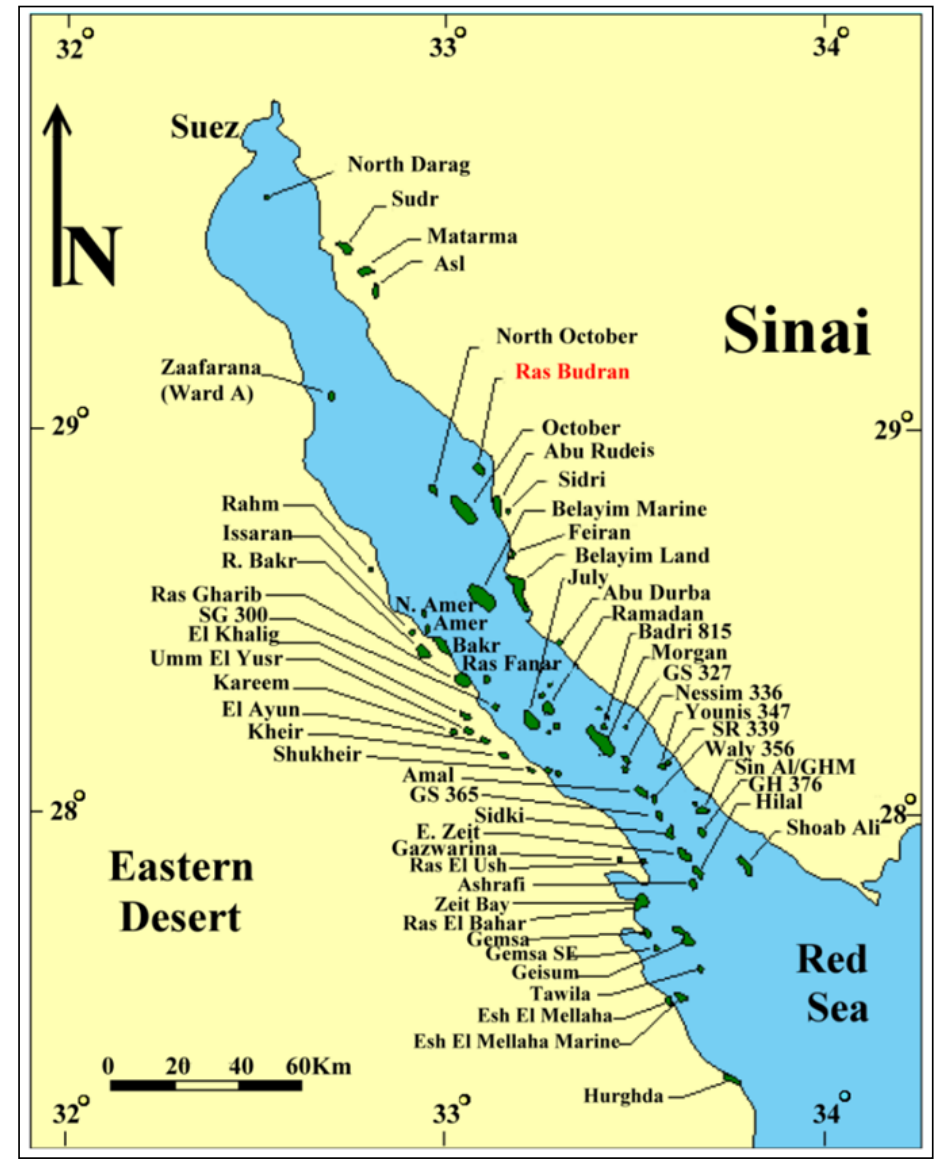

The Suez Gulf is considered one of the most important petroleum provinces in Egypt. Therefore, the petroleum source potential and types of OM of many Formations within the Gulf are documented by many authors (Shahin, 1988; Salah, 1992; Younes, 2001; El Nady, 2006; Abu Al-Atta et al., 2014; El Diasty et al., 2014; El Nady and Mohamed, 2016; El Nady et al., 2016; El Khadragy et al., 2017; Nabawy and El Sharawy, 2018). Also, many thermal maturity studies and geothermal gradient are investigated. Recently, From those literatures, Abdel Zaher et al (2014) examined the high geothermal gradient in the Gulf and founded that it is restricted to its margins and center, with the general trend of increasing toward the west that leads to increasing the opportunity of oil-bearing Formation to become mature at the lowest depth of high heat flow toward east Gulf margin and west toward the axial Gulf.Moreover, Abu Al-Atta (2014) and Atia et al. (2015)by studying the thermal maturation modeling of organic matters concluded that the younger organic-rich shales of the lower Miocene (Rift-infill) act as source rocks in some deep basin within the Gulf rift as an increase in the thermal maturity by increasing the burial depth.

The aim of the present study is focused on the application of the measured parameters of the RockEval pyrolysis data to determine the quantity, quality, thermal maturity of the OM constituent and transgression-regression cycles of a selected sedimentary sequence in the well EE85-1A. It is combined with the data obtained from the vitrinite reflectance to predict the geothermal gradient, total erosion thickness, and measures the stage of the thermal maturity. Consequently, a total of 54 cutting samples of sedimentary sequence of pre-Rift strata (Esna Shale, Thebes, and Darat Formations) and Rift-infill strata (Nukhul, Rudeis, and Kareem Formations) were geochemically analyzed to accomplishing this work.Also, an attempt to reveal the depth intervals of the oil window within the studied well from the relationship between the depth and Rowasillustrated within the present study by a statistical regression line. 


\section{Organic geochemistry of Paleocene - Middle Miocene Succession}

\section{GEOLOGICAL SETTING}

Ras Budran field has its own distinguished NE-SW anticlinal faulty block features extend to the western coast of Sinai (EGPC, 1996). The structure consists of northeast dipping flank (14 $\left.{ }^{\circ}-15^{\circ}\right)$ (Rahman and Zahran 1986) broken into several blocks by a system of step normal faults down steps to the south and southwest (Chowdhary and Taha 1987). The structure was formed contemporary the deposition of Rudeis Formation of the Lower Miocene according to Attia et al. (2015). The cumulative throw of these faults are measured by Khairy and Swidan (1992) attains $610 \mathrm{~m}$. Ali and Khairy (1996) state These faults have a combined horizontal and vertical displacements. The horizontal one is predominant and they transferred the older antithetic and synthetic rejuvenated gravitational faults with different lateral offsets. Henaish (2018) classified the geometry ofthe fault-related domes on the Suez Gulf to domes formed in strike-slip zones or domes formed by drag along normal fault and domes formed at transfer zones of normal faults. Accordingly, The antiform-structural faults in the Ras Budran area may relate to the first and the third types of fault-related dome structures.Zahra and Nakhla (2015) using 2D and 3D seismic data profiles attribute the complexity of the Pre-Miocene structure of Ras Budran area due to the effect of faults at different levels and various directions.

The sedimentary sequence in Ras Budran area, as recorded in the drilled wells of Ras Budran oil field, ranges in age from Paleozoic to Recent.The EE85-1A well penetrate throughout a sedimentary sequence from the Holocent till the Upper Carboniferous with a total drill thickness of about $3829.51 \mathrm{~m}$ (Fig. 2). The selected sequence within the well under investigation is differentiated from the top to the bottom into; Kareem, Rudeis, Nukhul, Tayiba, Darat, Thebes, and Esna shale. Cutting samples from Tayiba Red Bed and anhydrite at the base of Kareem Formations are excluded. Kareem Formation $(178.61 \mathrm{~m})$; is composed mainly of limestone with shale, sandstone, and anhydrite bands. Rudeis Formation (421.06 m) is mainly composed of limestone with shale bands. Nukhul Formation $(74.02 \mathrm{~m})$ is characterized mainly of shale with limestone, and sandstone interbeds.Darat $(48.16 \mathrm{~m})$ and Thebes $(285.29 \mathrm{~m})$ Formations have nearly the same lithology that consists mainly of limestone. Esna Shale Formation ( $44.20 \mathrm{~m}$ ) is composed mainly of shale.

\section{SAMPLING AND METHODS}

A total of 54 cutting samples selected andprepared for geochemical analysis. Eight, twenty-one, four, three, fifteen, and three samples are collected from Kareem, Rudeis, Nukhul, Darat, Thebes and Esna Shale Formations in respective order.About 70 to $80 \mathrm{mg}$ of the bulk sample mode were analyzed using the Rock-Eval- 6 instrumentin the laboratory of the Egyptian Petroleum Research Institute.The measured and calculated parameters from the Rock-Eval techniques are considered in the present study.The measured parameters are:S1, free volatile hydrocarbon content flushed away at $300^{\circ} \mathrm{C}(\mathrm{mg} \mathrm{HC} / \mathrm{g}$ rock); $\mathrm{S} 2$, the cracked hydrocarbon from solid kerogen at temp between $300-600^{\circ} \mathrm{C} ; \mathrm{S} 3$, carbon dioxide generating from the pyrolysis of $\mathrm{OM}(\mathrm{mg} \mathrm{CO} / \mathrm{g}$ rock); Tmax, the pyrolysis temperature at the peak maximum of $\mathrm{S} 2$ (Tissot and Welte, 1984; Espitalie et al. 1997).

The calculated parameters are HI, hydrogen index $=\mathrm{S} 2 \times 100 / \mathrm{TOC}(\mathrm{mg} \mathrm{HC} / \mathrm{g}$ rock); OI, oxygen index $=\mathrm{S} 3 \times 100 / \mathrm{TOC}(\mathrm{mg} \mathrm{CO} / \mathrm{g} \mathrm{TOC}) ; \mathrm{S} 2 / \mathrm{S} 3$ (for determine Type of Kerogen; PY, potential yield = S1 $+\mathrm{S} 2(\mathrm{mg} \mathrm{HC} / \mathrm{g}$ rock); $\mathrm{PI}=$ production index $=\mathrm{S} 1 / \mathrm{S} 1+\mathrm{S} 2$; OSI, oil saturation index $=\mathrm{S} 1 \times 100 / \mathrm{TOC}$; RHP, relative hydrocarbon potential $=(\mathrm{S} 1+\mathrm{S} 2) / \mathrm{TOC}$ (Fang et al., 1993; Peters and Cassa, 1994; Hunt, 1996; Espitalie et al., 1997; Fowler et al., 2005; Gürgey and Bati, 2018).

Another portion of the samples was crushed to a grain size of 850 um then treatment by $\mathrm{HCl}$ and $\mathrm{HF}$ to concentrate the OM (Barker 1996). Polished samples of the remain dispersed OM is made for determining the Random vitrinite reflectance (Ro). Ro is measured according to the intensity of the light reflected from the surface of the collotelinite maceral of vitrinite maceral group. For each sample a constant of 20 counted points under incident, monochromatic light, oil immersion objective and calibration standards (ISO 7404/5, 2009) are measured in the Institute of rock structure and mechanics at the Czech Republic. Statistical relationships and fit linear regression between the components of depth, and the obtained data of vitrinite reflectance are carried out using Origin-Pro statistical-graphical software version 8 . 
Khaled, K. A. M. and Edress, N. A. A.

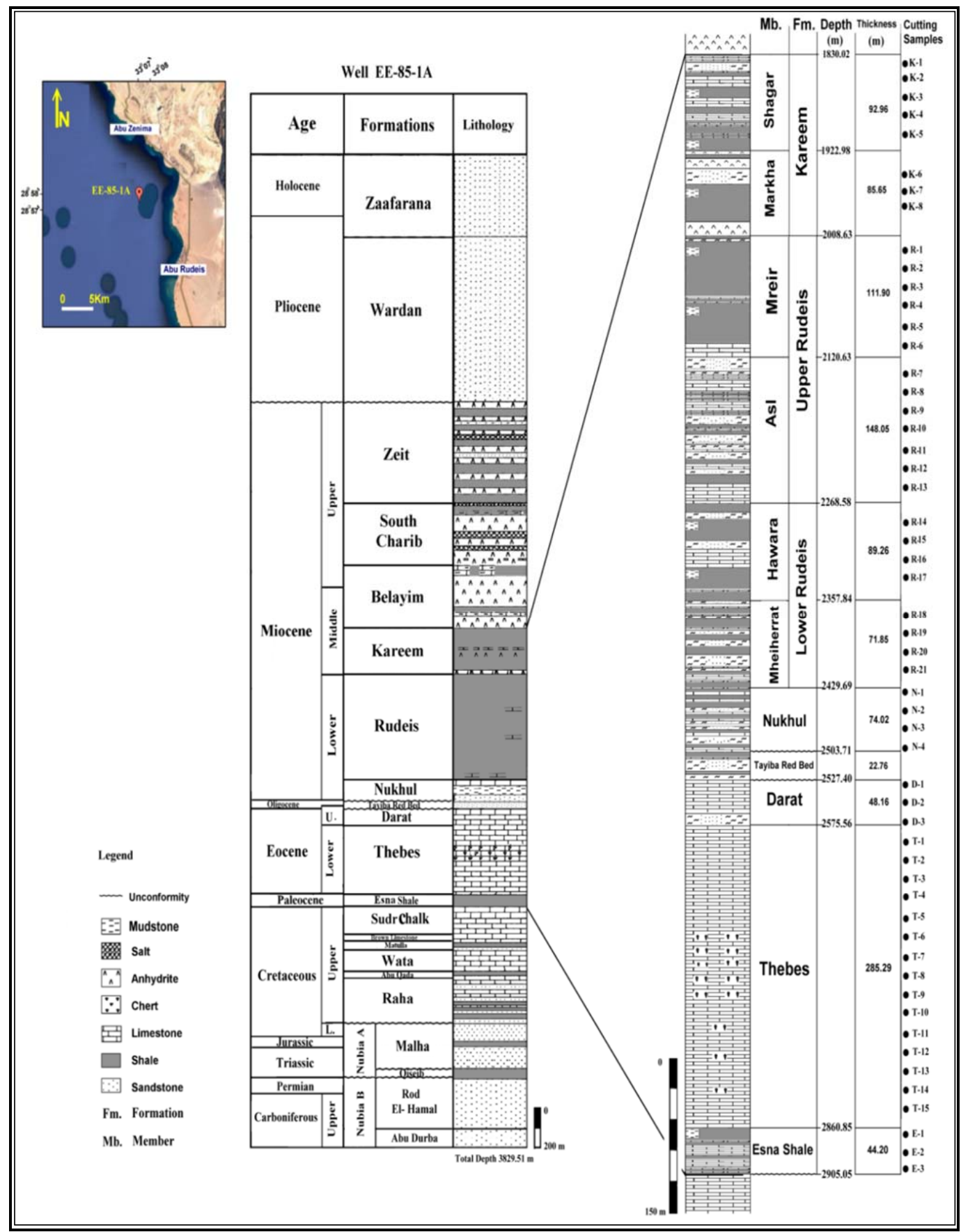

Fig. 2: The drilled lithostratigraphic sections of the EE85-1A well on the left and the selected sedimentary sequence at the right.

\section{RESULTS}

The obtained Rock-Eval data from the selected sedimentary sequence (Table 1) were used for the purpose of both determine the hydrocarbon potential of the enclosing Formations (Kareem, Rudeis, Nukhul, Darat, Thebes, and Esna Shale) in one hand, and to examine the fluctuation of sea level during their deposition on the other hand. Vitrintere reflectance data also give an optimal application for detecting geothermal gradient, measuring the missing thickness of sediments at the studied well, and predict thermal maturity of organic carbon. Moreover, statistically, relationship using Ro and burial depth gives an idea to predict the oil widow interval within the studied well. 


\section{Organic geochemistry of Paleocene - Middle Miocene Succession}

To obtain a real interpretation of the obtained results, either sample contaminated by liquid hydrocarbon or overmature samples is excluded. The first is recognized by the amounts of the values of OSI $=(\mathrm{S} 1 / \mathrm{TOC}) \times 100$ (Jarvie et al., 2001). All the present samples have the oil saturated index in the ranges between 3.71 and 71.59 . S1 versus TOC diagram shows there are no samples proceed the line OSI=1 (Fig. 3).

The postmature samples are recognized essential based on Ro and Tmax values in the present study (Peter and Casse, 1994; Rahmani et al., 2013). The Tmax values of the studied samples are ranging from $419^{\circ} \mathrm{C}$ to $430^{\circ} \mathrm{C}$ whereas the Ro ranges from 0.32 to 0.62 . Both values of Tmax and Ro show an increase in its values of younger to older Formations throughout the studied well (ie; they increase with increasing the burial depth).

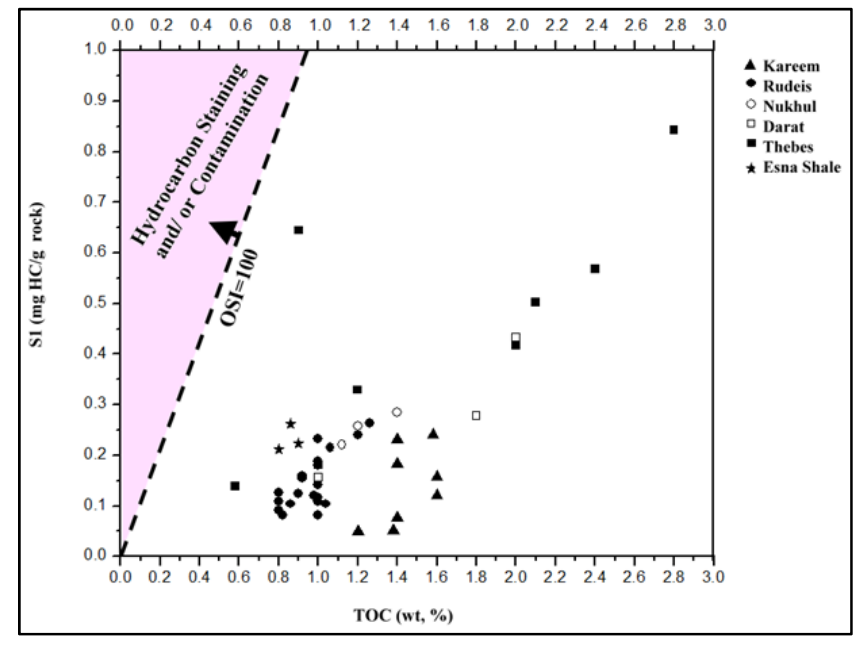

Fig. 3. Plot diagram of S1versus TOC diagram showing the possible contamination of the studied cutting samples by the liquid release hydrocarbons (Jarvie et al. 2001)

\section{The quantity of organic richness}

Quantity of the OM is generally expressed by the amounts of TOC (wt, \%), S1, and S2 (Tissot and Welte, 1984; Peters and Cassa, 1994; Hunt, 1996). The TOC values through depths show that the minimum values of TOC are recorded within the intervals $2008 \mathrm{~m}$ to $2430 \mathrm{~m}(0.8-1.2 \mathrm{wt}$, \%) of the Rudeis Formationand from $2860 \mathrm{~m}$ to $2905 \mathrm{~m}(0.8-0.9 \mathrm{wt}, \%)$ of the Esna Shale Formation (Table 1; Fig. 4). The intermediate values of TOC are measured within the Kareem (1.2 -1.6 wt \%), the Nukhul (1.12-1.2 wt, \%), and the Darat (1-1.8 wt, \%) Formations. The recorded highest values belong to the Thebes Formation of TOC ranges from 0.58 to $5.3 \mathrm{wt}, \%$ TOC (average; $3.2 \mathrm{wt}, \%$ TOC). The other parameters of S1 and S2 confirmed that the sole zone of the studied sequence exhibits intermediate to high values of S1 (0.14-2.9; average $0.48 \mathrm{mg} \mathrm{HC} / \mathrm{gm}$ rock) and S2 (1.01-38.42; average $6.9 \mathrm{mg} \mathrm{HC} / \mathrm{gm}$ rock). The other Formations of the Kareem, the Rudeis, the Nukhul, the Darat, and the Esna Shale have a minimum S1 (0.05-0.43 mg $\mathrm{HC} / \mathrm{gm}$ rock) and S2 (0.43-3.5 $\mathrm{mg} \mathrm{HC/gm} \mathrm{rock)} \mathrm{values.}$

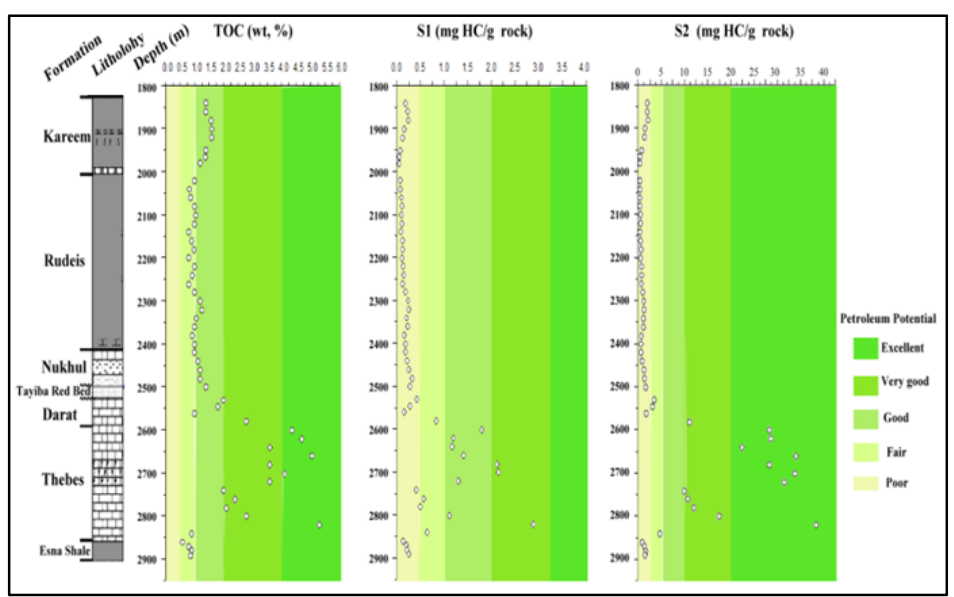

119
Fig. 4. Plot diagrams of TOC, S1, and S2 versus the burial depth of the studied Formations (Peters and Cassa 1994). 
Table 1.TOC, Rock-Eval pyrolysis, and vitrinite reflectance data and indices of Kareem, Rudeis, Nukhul, Darat, Thebes, and Esna Shale formations, Wells no. EE85-1A, Ras Budran area.

\begin{tabular}{|c|c|c|c|c|c|c|c|c|c|c|c|c|c|c|c|}
\hline 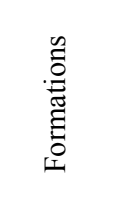 & 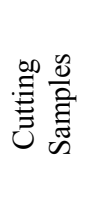 & $\begin{array}{l}\text { Depth } \\
\text { (m) }\end{array}$ & $\begin{array}{c}\text { TOC } \\
\text { (wt, \%) }\end{array}$ & 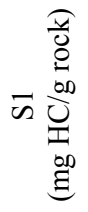 & 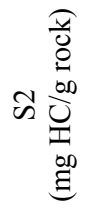 & 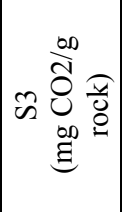 & $\begin{array}{c}\text { Tmax } \\
\left({ }^{\circ} \mathrm{C}\right)\end{array}$ & $\begin{array}{l}\text { Ro } \\
(\%)\end{array}$ & 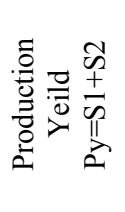 & $\begin{array}{l}\tilde{\tilde{n}} \\
\hat{\Omega}\end{array}$ & 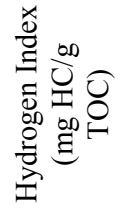 & 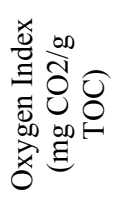 & 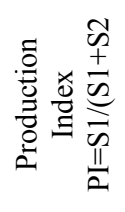 & 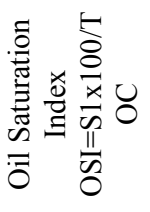 & 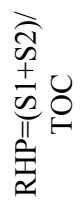 \\
\hline \multirow{8}{*}{ Kareem } & K-1 & 1840 & 1.4 & 0.18 & 2.1 & 1.4 & 419 & 0.32 & 2.28 & 1.5 & 150 & 100 & 0.08 & 12.86 & 1.63 \\
\hline & K-2 & 1860 & 1.4 & 0.23 & 2.09 & 1.4 & 421 & 0.33 & 2.32 & 1.49 & 149.29 & 100 & 0.1 & 16.43 & 1.66 \\
\hline & K-3 & 1880 & 1.58 & 0.24 & 2.17 & 1.64 & 422 & 0.33 & 2.41 & 1.32 & 137.34 & 103.8 & 0.1 & 15.19 & 1.52 \\
\hline & K-4 & 1900 & 1.6 & 0.16 & 1.6 & 1.86 & 423 & 0.34 & 1.76 & 0.86 & 100 & 116.25 & 0.09 & 10 & 1.1 \\
\hline & K-5 & 1920 & 1.6 & 0.12 & 1.4 & 2.21 & 423 & 0.34 & 1.52 & 0.63 & 87.5 & 138.12 & 0.08 & 7.5 & 0.95 \\
\hline & K-6 & 1950 & 1.4 & 0.08 & 0.87 & 1.51 & 424 & 0.35 & 0.95 & 0.58 & 62.14 & 107.86 & 0.08 & 5.71 & 0.68 \\
\hline & $\mathrm{K}-7$ & 1965 & 1.38 & 0.05 & 0.52 & 1.38 & 423 & 0.34 & 0.57 & 0.38 & 37.68 & 100 & 0.09 & 3.62 & 0.41 \\
\hline & K-8 & 1980 & 1.2 & 0.05 & 0.44 & 1.44 & 423 & 0.35 & 0.49 & 0.3 & 36.67 & 120 & 0.1 & 4.17 & 0.41 \\
\hline \multirow{21}{*}{ Rudeis } & $\mathrm{R}-1$ & 2020 & 1 & 0.08 & 0.5 & 1.98 & 422 & 0.35 & 0.58 & 0.25 & 50 & 198 & 0.14 & 8 & 0.58 \\
\hline & $\mathrm{R}-2$ & 2040 & 0.82 & 0.08 & 0.43 & 1.64 & 422 & 0.35 & 0.51 & 0.26 & 52.44 & 200 & 0.16 & 9.76 & 0.62 \\
\hline & R-3 & 2060 & 0.86 & 0.1 & 0.47 & 1.72 & 423 & 0.35 & 0.57 & 0.27 & 55.65 & 200 & 0.17 & 11.63 & 0.66 \\
\hline & R-4 & 2080 & 1 & 0.12 & 0.5 & 2.02 & 422 & 0.34 & 0.62 & 0.25 & 50 & 202 & 0.19 & 12 & 0.62 \\
\hline & R-5 & 2100 & 1.04 & 0.1 & 0.55 & 2.08 & 422 & 0.34 & 0.65 & 0.26 & 52.88 & 200 & 0.15 & 9.61 & 0.62 \\
\hline & R-6 & 2120 & 1 & 0.11 & 0.57 & 2 & 424 & 0.35 & 0.68 & 0.28 & 57 & 200 & 0.16 & 11 & 0.68 \\
\hline & $\mathrm{R}-7$ & 2140 & 0.8 & 0.09 & 0.52 & 1.58 & 424 & 0.35 & 0.61 & 0.33 & 65 & 197.5 & 0.15 & 11.25 & 0.76 \\
\hline & R-8 & 2160 & 0.9 & 0.12 & 0.65 & 1.64 & 424 & 0.36 & 0.77 & 0.4 & 72.22 & 182.22 & 0.16 & 13.33 & 0.85 \\
\hline & R-9 & 2180 & 0.98 & 0.12 & 0.73 & 1.8 & 424 & 0.36 & 0.85 & 0.4 & 74.49 & 183.67 & 0.14 & 12.24 & 0.87 \\
\hline & $\mathrm{R}-10$ & 2200 & 0.8 & 0.11 & 0.62 & 1.44 & 423 & 0.37 & 0.73 & 0.43 & 77.5 & 180 & 0.15 & 13.75 & 0.91 \\
\hline & R-11 & 2220 & 1 & 0.14 & 0.8 & 1.66 & 423 & 0.37 & 0.94 & 0.48 & 80 & 166 & 0.15 & 14 & 0.94 \\
\hline & R-12 & 2240 & 0.92 & 0.15 & 0.87 & 1.49 & 422 & 0.37 & 1.02 & 0.58 & 95.57 & 161.96 & 0.15 & 16.3 & 1.11 \\
\hline & R-13 & 2260 & 0.8 & 0.13 & 0.78 & 1.18 & 423 & 0.37 & 0.91 & 0.66 & $\begin{array}{l}97.5 \\
\end{array}$ & 147.5 & 0.14 & 16.25 & 1.14 \\
\hline & R-14 & 2280 & 1 & 0.18 & 1.02 & 1.44 & 423 & 0.37 & 1.2 & 0.71 & 102 & 144 & 0.15 & 18 & 1.2 \\
\hline & R-15 & 2300 & 1.2 & 0.24 & 1.26 & 1.68 & 423 & 0.37 & 1.5 & 0.75 & 105 & 140 & 0.16 & 20 & 1.25 \\
\hline & R-16 & 2320 & 1.26 & 0.26 & 1.39 & 1.71 & 423 & 0.38 & 1.65 & 0.81 & 110.32 & 135.71 & 0.16 & 20.63 & 1.31 \\
\hline & R-17 & 2340 & 1.06 & 0.21 & 1.22 & 1.38 & 423 & 0.38 & 1.43 & 0.88 & 115.1 & 130.19 & 0.15 & 19.81 & 1.35 \\
\hline & R-18 & 2360 & 1 & 0.23 & 1.22 & 1.4 & 422 & 0.37 & 1.45 & 0.87 & 122 & 140 & 0.16 & 23 & 1.45 \\
\hline & R-19 & 2380 & 0.92 & 0.16 & 0.78 & 1.47 & 423 & 0.38 & 0.94 & 0.53 & 84.78 & 159.78 & 0.17 & 17.39 & 1.02 \\
\hline & R-20 & 2400 & 1 & 0.19 & 0.75 & 1.8 & 423 & 0.38 & 0.94 & 0.42 & 75 & 180 & 0.2 & $\begin{array}{l}19 \\
\end{array}$ & 0.94 \\
\hline & $\mathrm{R}-21$ & 2420 & 1 & 0.18 & 0.72 & 1.62 & 424 & 0.37 & 0.9 & 0.44 & 72 & 162 & 0.2 & 18 & 0.9 \\
\hline \multirow{3}{*}{ Nukhul } & $\mathrm{N}-1$ & 2440 & 1.12 & 0.22 & 1.01 & 1.57 & 425 & 0.38 & 1.23 & 0.64 & 90.18 & 140.18 & 0.18 & 19.64 & 1.1 \\
\hline & $\mathrm{N}-2$ & 2460 & 1.2 & 0.26 & 1.35 & 1.44 & 425 & 0.38 & 1.61 & 0.94 & 112.5 & 120 & 0.16 & 21.67 & 1.34 \\
\hline & $\mathrm{N}-3$ & 2480 & 1.2 & 0.33 & 1.5 & 1.2 & 424 & 0.38 & 1.83 & 1.25 & 125 & 100 & 0.18 & 27.5 & 1.52 \\
\hline
\end{tabular}


Cont. Table

\begin{tabular}{|c|c|c|c|c|c|c|c|c|c|c|c|c|c|c|c|}
\hline 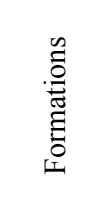 & 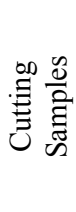 & $\begin{array}{l}\text { Depth } \\
\text { (m) }\end{array}$ & $\begin{array}{c}\text { TOC } \\
\text { (wt, \%) }\end{array}$ & 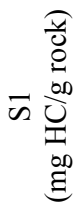 & 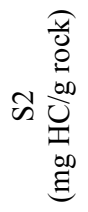 & 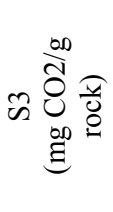 & $\begin{array}{c}\text { Tmax } \\
\left({ }^{\circ} \mathrm{C}\right)\end{array}$ & $\begin{array}{l}\text { Ro } \\
(\%)\end{array}$ & 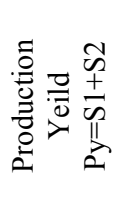 & $\begin{array}{l}\tilde{\tilde{n}} \\
\tilde{N}\end{array}$ & 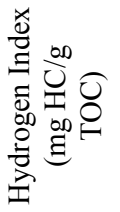 & 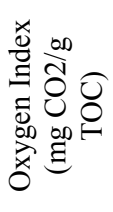 & 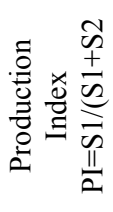 & 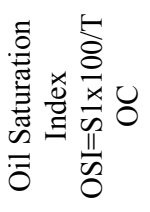 & 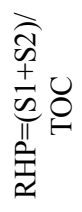 \\
\hline \multirow{4}{*}{ Darat } & $\mathrm{N}-4$ & 2500 & 1.4 & 0.28 & 1.75 & 1.48 & 425 & 0.39 & 2.03 & 1.18 & 125 & 105.71 & 0.14 & 20 & 1.45 \\
\hline & D-1 & 2530 & 2 & 0.43 & 3.5 & 2.6 & 425 & 0.4 & 3.93 & 1.35 & 175 & 130 & 0.11 & 21.5 & 1.96 \\
\hline & D-2 & 2545 & 1.8 & 0.28 & 3.19 & 2.52 & 424 & 0.41 & 3.47 & 1.26 & 177.22 & 140 & 0.08 & 15.55 & 1.93 \\
\hline & D-3 & 2560 & 1 & 0.16 & 1.8 & 1.12 & 422 & 0.42 & 1.96 & 1.61 & 180 & 112 & 0.08 & 16 & 1.96 \\
\hline \multirow{15}{*}{ Thebes } & T-1 & 2580 & 2.8 & 0.84 & 11.2 & 2.24 & 424 & 0.42 & 12.04 & 5 & 400 & 80 & 0.07 & 30 & 4.3 \\
\hline & T-2 & 2600 & 4.36 & 1.8 & 28.34 & 3.49 & 420 & 0.44 & 30.14 & 8.12 & 650 & 80.04 & 0.06 & 41.28 & 6.91 \\
\hline & T-3 & 2620 & 4.7 & 1.2 & 28.76 & 3.85 & 418 & 0.43 & 29.96 & 7.47 & 611.81 & 81.91 & 0.04 & 25.53 & 6.37 \\
\hline & T-4 & 2640 & 3.6 & 1.18 & 22.41 & 2.16 & 419 & 0.44 & 23.59 & 10.37 & 622.5 & 60 & 0.05 & 32.78 & 6.55 \\
\hline & T-5 & 2660 & 5.06 & 1.42 & 34.15 & 3.14 & 420 & 0.45 & 35.57 & 10.87 & 674.9 & 62.05 & 0.04 & 28.06 & 7.03 \\
\hline & T-6 & 2680 & 3.6 & 2.13 & 28.35 & 2.16 & 423 & 0.46 & 30.48 & 13.12 & 787.5 & 60 & 0.07 & $\begin{array}{l}59.17 \\
\end{array}$ & 8.47 \\
\hline & T-7 & 2700 & 4.1 & 2.16 & 33.82 & 2.87 & 425 & 0.47 & 35.98 & 11.78 & 824.88 & 70 & 0.06 & 52.68 & 8.77 \\
\hline & T-8 & 2720 & 3.6 & 1.31 & 31.5 & 4.32 & 426 & 0.49 & 32.81 & 7.29 & 875 & 120 & 0.04 & 36.39 & 9.11 \\
\hline & T-9 & 2740 & 2 & 0.42 & 10 & 2.12 & 424 & 0.5 & 10.42 & 4.72 & 500 & 106 & 0.04 & 21 & 5.21 \\
\hline & T-10 & 2760 & 2.4 & 0.57 & 10.8 & 1.92 & 425 & 0.52 & 11.37 & 5.62 & 450 & 80 & 0.05 & 23.75 & 4.74 \\
\hline & T-11 & 2780 & 2.1 & 0.5 & 12.07 & 1.34 & 425 & 0.54 & 12.57 & 9 & 574.76 & 63.8 & 0.04 & 23.91 & 5.98 \\
\hline & T-12 & 2800 & 2.8 & 1.12 & 17.5 & 3.36 & 426 & 0.55 & 18.62 & 5.21 & 625 & 120 & 0.06 & 40 & 6.65 \\
\hline & T-13 & 2820 & 5.3 & 2.9 & 38.42 & 15.05 & 428 & 0.58 & 41.32 & 2.55 & 724.9 & 283.96 & 0.07 & $\begin{array}{l}54.72 \\
\end{array}$ & 7.8 \\
\hline & T-15 & 2840 & 0.9 & 0.64 & 4.72 & 1.98 & 429 & 0.59 & 5.36 & 2.38 & 524.44 & 220 & 0.12 & 71.11 & 5.95 \\
\hline & T-15 & 2860 & 0.58 & 0.14 & 1.01 & 0.99 & 430 & 0.6 & 1.15 & 1.02 & 175.14 & 170.69 & 0.12 & 24.14 & 1.98 \\
\hline \multirow{3}{*}{$\begin{array}{l}\text { Esna } \\
\text { Shale }\end{array}$} & E-1 & 2870 & 0.8 & 0.21 & 1.42 & 1.31 & 430 & 0.61 & 1.63 & 1.08 & 177.5 & 163.75 & 0.13 & 26.25 & 2.04 \\
\hline & E-2 & 2880 & 0.9 & 0.22 & 1.64 & 1.49 & 430 & 0.61 & 1.86 & 1.1 & 182.22 & 165.55 & 0.12 & 24.44 & 2.07 \\
\hline & E-3 & 2890 & 0.86 & 0.26 & 1.61 & 1.46 & 430 & 0.62 & 1.87 & 1.1 & 187.21 & 169.77 & 0.14 & 30.23 & 2.17 \\
\hline
\end{tabular}


By plotting of the calculated production yield $(\mathrm{S} 1+\mathrm{S} 2)$ against the TOCvalues of the studied sedimentary sequence on the diagram of Ghori and Haines (2007) indicate that; the majority samples of the Kareem and the Rudies Formations fit in the area of poor potential; the samples represents the Nukhul, the Darat, and the Esna Shale Formations are located in the fair area, while the 13 samples of the Thebes (87\%) lay in the areas of verygood to excellent potential (Fig. 5).

Fig. 5. Plot diagram of Production yield versus TOC of the studied Formations (Ghori and Haines 2007).

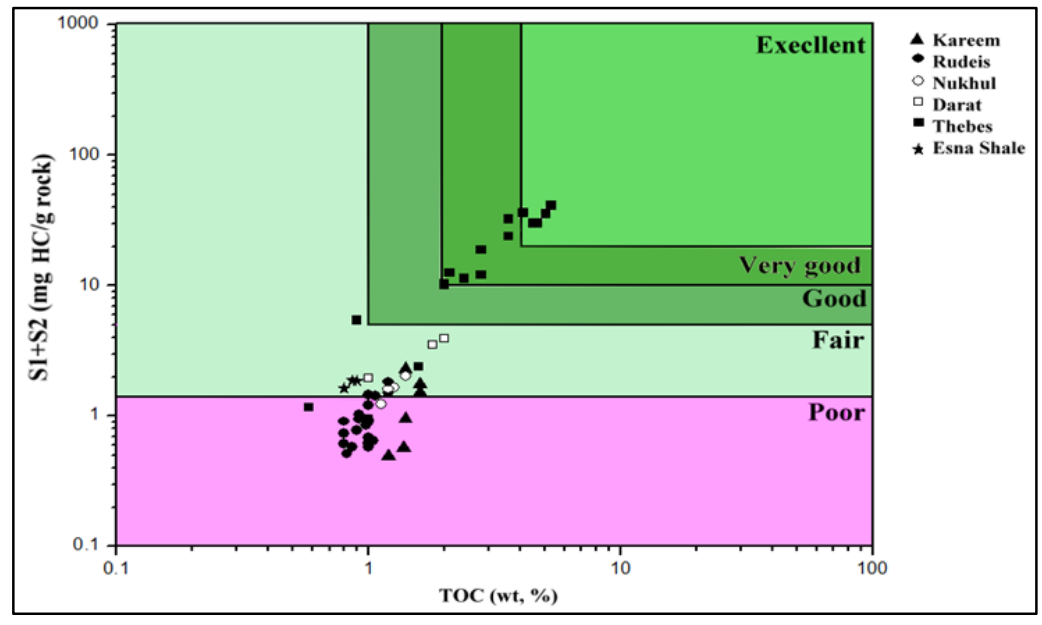

\section{Kerogen types}

Generally, three and/or four main types of kerogen within the studied sedimentary sequence are distinguished (Figs. $6 \& 7$ ). Type I and Type II are the genetic precursor of oil.Type II/III ${ }^{\mathrm{b}}$ is in between Type II \& III of either oil and/or gas prone. Type III of terrestrial plants of dominatinggasprone and Type IV of inert carbonor oxidized OM (Tissot and Welte, 1984; Waples, 1985; Jacobson, 1991; Van Krevelen, 1993; Peters and Cassa, 1994; Hunt, 1996; Espitalie et al 1997).

The expelled product at the peak maturity is depended essentially on the types of kerogen. The main geochemical parameters identify the kerogen types are $\mathrm{HI}(\mathrm{mg} \mathrm{HC} / \mathrm{g} \mathrm{TOC}$ ) and $\mathrm{S} 2 / \mathrm{S} 3$ ratio (Peter and Cassa, 1994). The calculated HI values of the studied samples show that the Kareem, the Rudeis, the Nukhul, and The Esna Shale Formations are belonged to type III kerogen of HI values between 50-200 mg HC/g TOC, with the exception of the Lower Kareem and Upper Rudeis Formation of inert Type-IV Kerogen have of HI values less than $50 \mathrm{mg} \mathrm{HC} / \mathrm{g}$ TOC. All samples of the Thebes Formationare located within Type I ( $40 \%$, of HI $>600 \mathrm{mg} \mathrm{HC} / \mathrm{g} \mathrm{TOC})$ and Type II (60\% of HI between $300-600 \mathrm{mg} \mathrm{HC} / \mathrm{g}$ TOC). The $\mathrm{S} 2 / \mathrm{S} 3$ ratios of the studied sequence show more reducing the types of kerogen than HI values (Fig. 7). The inert Type IV is prolonged from the lower Kareem Formation to cover the entire Rudeis Formation of S2/S3 ratio < 1. Type III is characterized the Upper Kareem, The Nukhul, The Darat, and The Esna Shale Formations of S2/S3 ratio range from 1 to 5. The Thebes Formation displays three different types (Type II, 27\%; Type II/III, $40 \%$, and Type III, 33 $\%$ ) of $\mathrm{S} 2 / \mathrm{S} 3$ ratios range between 10-15, 5-10, and 1-5 in respect order (Fig. 7).

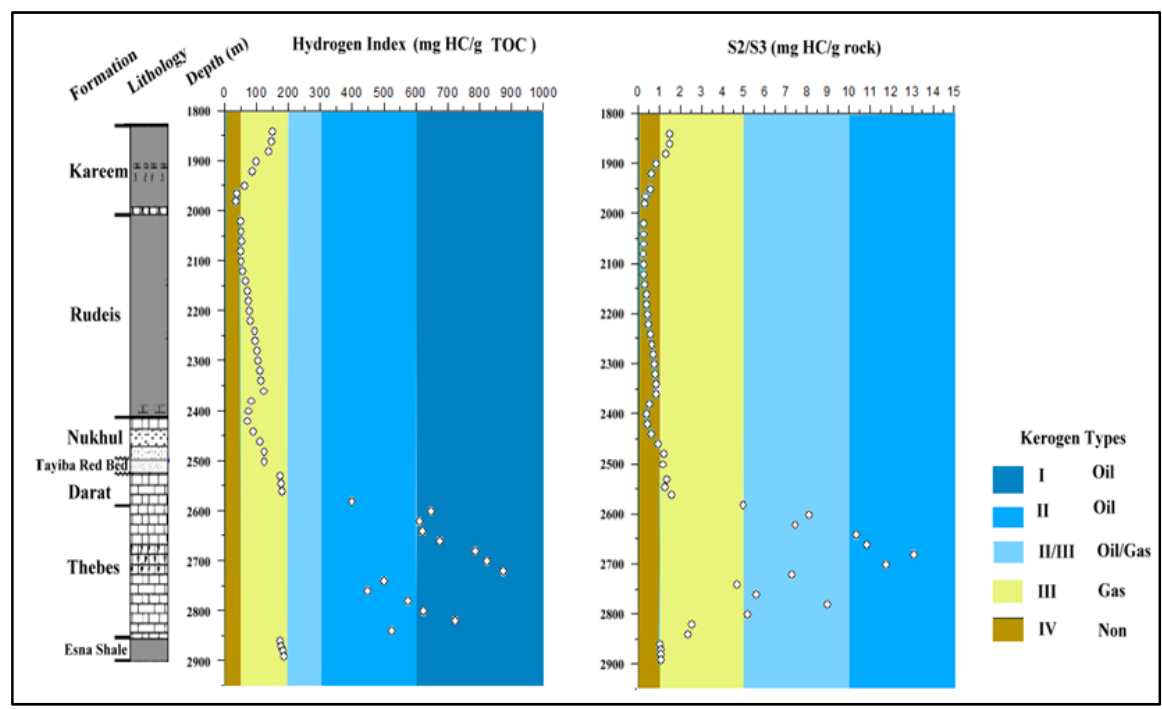

Fig. 6. Kerogen types diagram of the studied Formations based on Peter and Cassa (1994). 
Fig. 7. Plot diagram of HI versus OI diagram of the studied Formations (van Krevelen 1993).

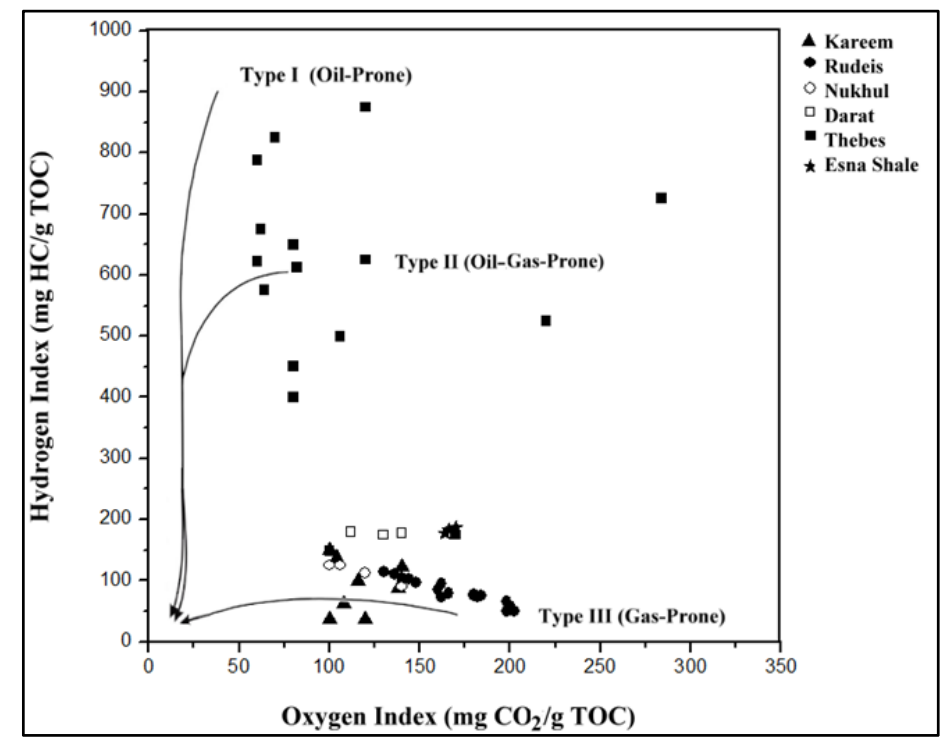

By the plotting of the studied samples on HI versus OI diagram established by Van Krevelen (1993) (Fig. 8). The samples of study Formations of the Kareem, the Rudeis, the Nukhul, the Darat, and the Esna Shale reveal a Type III, with a little bit of Type IV of three samples belong Kareem Formation. On the other hand samples of the Thebes Formation are situated within the areas of Type I and Type II of oil and oil/gas-prone respectively.

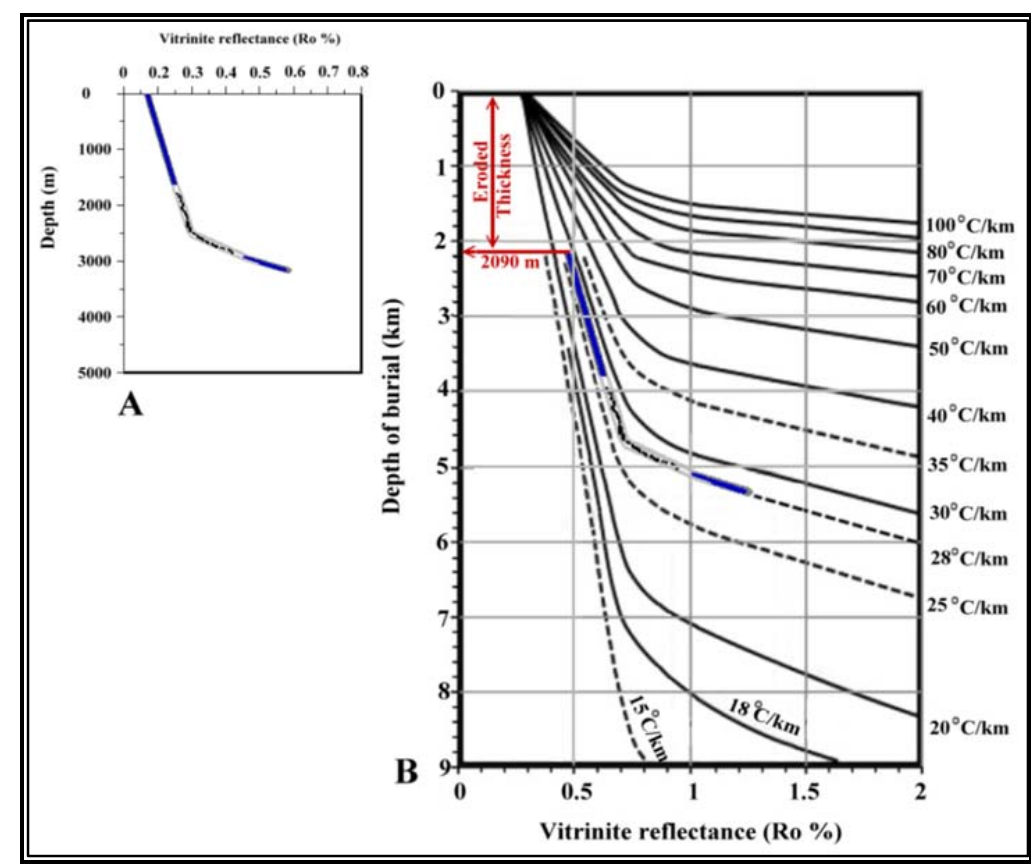

Fig. 8: Plot diagram of vitrinite reflectance versus the burial depth of the studied Formations on the left, and the same diagram was plotted on the standard Suggate diagram on the right (Suggate 1998).

\section{Maturity}

The rate of the decomposition and alteration of OMto produce oil, wet gas, and finally, dry gas with the increasing temperature, depth, pressures, and time is called maturity (van Krevelen, 1993). Other important factors affect the maturity is the quality and quantity of OM encompass the sedimentary strata (Tissot and Welte, 1984). The measure of the degree of thermal maturity of the studied sedimentary sequence is determined by the Rock-Eval Tmax, PI, and by the measurements of $\mathrm{R}_{\mathrm{O}}$ (Peters and Cassa, 1994; Taylor et al., 1998).

The measured Tmax for the whole studied sequence ranges from $419^{\circ} \mathrm{C}$ for younger Kareem Formation to reach its maximum value of $430^{\circ} \mathrm{C}$ for the oldest Esna Shale Formation. The PI values of the whole formation show the generative potential of low values immature $(37 \%$; PI $<1)$ to dominate early mature of the majority of samples of $73 \%$ of 1-0.2 PI (Table 1). 
Vitrinite reflectance data assemble to the Tmax values initiates with the low values $(0.32 \%)$ for younger strata and reach progressively to its maximum values $(0.62 \%)$ for the oldest Esna Shale Formation in the studied sequence.

The relationship between vitrinite reflectance against depth observes that the depth of $2500 \mathrm{~m}$ appears to separate the low-rank gradient of the Kareem, the Rudeis, and the Nukhul Formations from the high-rank gradient of the Darat, the Thebes, and the EsnaShale Formations. The measurements of vitrinite reflectance data after preceding that depth increase six times than its values in the upper sequence at the similar depth interval (Fig. 9A). An estimation of the thickness of eroded sediments in term of maximum depth of burial of the studied sequence is established according to Suggate (1998). The profile of the Roagainst the depth (Fig. 8A) is plotted on the standard diagram with taking into account the slope of low-rank gradient and curve of bending and the slope of the high-rank gradients. The fittest linesmatching with the proper profile perfectly match with the line of the geothermal gradient of $28^{\circ} \mathrm{C} / \mathrm{km}$. The subtraction distance of the upper-end line of zero depth to the standard profile of Suggate is used to presume the maximum burial depth of the selected sequence of approximately 2090m (Fig. 8B).

Fig. 9: Plot diagram of production Index versus Tmax of the studied Formations (Ghori and Hains 2007).

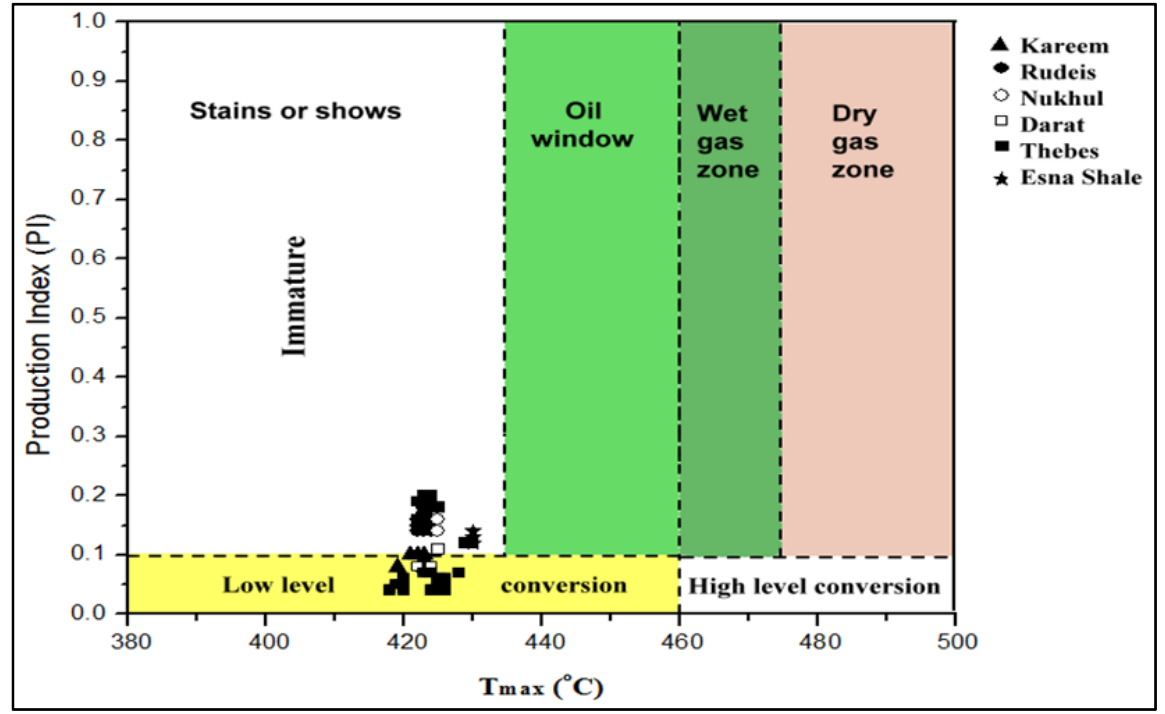

Thermal maturity is also illustrated by the plotting of the studied samples on the thermal maturity diagrams of both Chori \& Haines (2007) of the Tmax against PI and Tmax versus HI according to Koerverdon et al. (2011)(Figs. 9 \&10). The half of samples lay within the area of low-level conversion and half within stains or a show on the immature stage of maturation (Fig. 9). Koeverdon diagram shows also the premiere of the Thebes Formation of Type I, II, and II/III than other studied Formations of Type III, IV-III, and IV. Although the entire formation site in the immature zone with the exception of marginally mature in case of Esna Shale samples (Fig. 10).

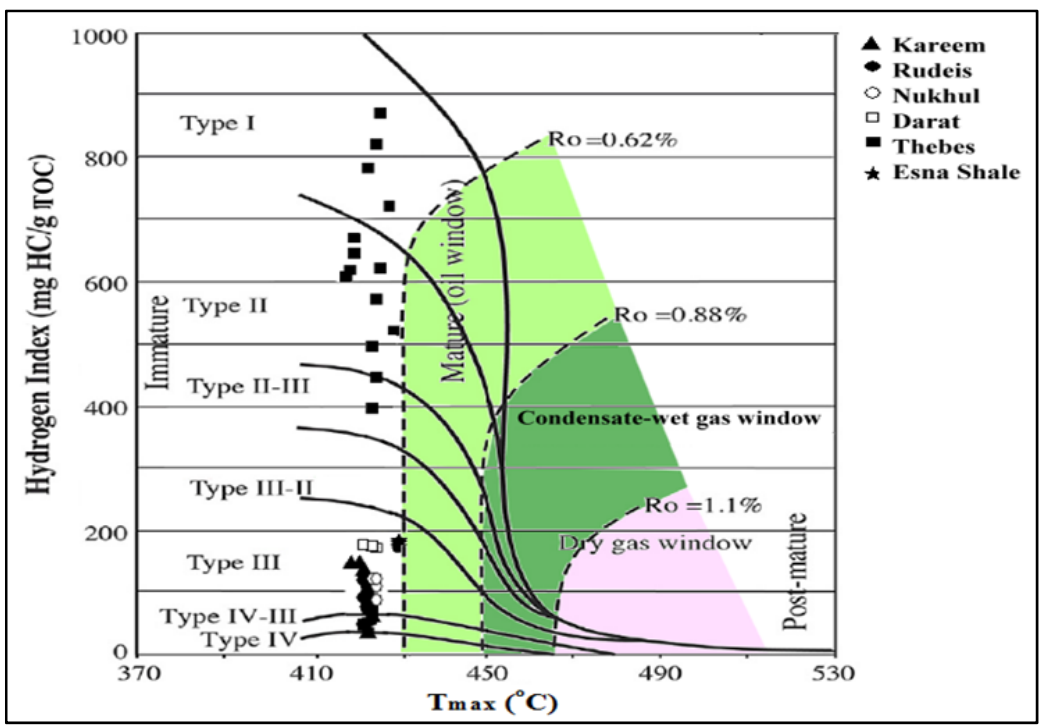

Fig. 10. Plot diagram of Hydrogen Index versus Tmax diagram of the studied Formations (Koeverdon et al. 2011). 


\section{Potential sea level sysles and detecting oil window interval}

The relative hydrocarbon potential RHP (=S1+S2/TOC) parameter derives from the Rock-Eval can be used as proxies for sea level oscillation (Fang et al., 1993, Gürgey and Bati, 2018). The present studies of the studied sequence show two major cycles (Fig. 11). The lower cycle is characterized by RHP $>2$ in which the highest sea level is recorded (9.11 RHP) at the middle part of the Thebes Formation.In contrast, the upper cycle is distinguished by RHP $<2$ in which the lowest sea level is recorded(0.41 RHP) within the Lower part of the Kareem Formation (Table 1; Fig. 11).

Within these major cycles, a minor sea level oscillationis pointed out, of four oscillations related to the lower major cycle and of five oscillations in the upper major cycle of the relative dominance of anoxic-oxic conditions (Fig. 11).

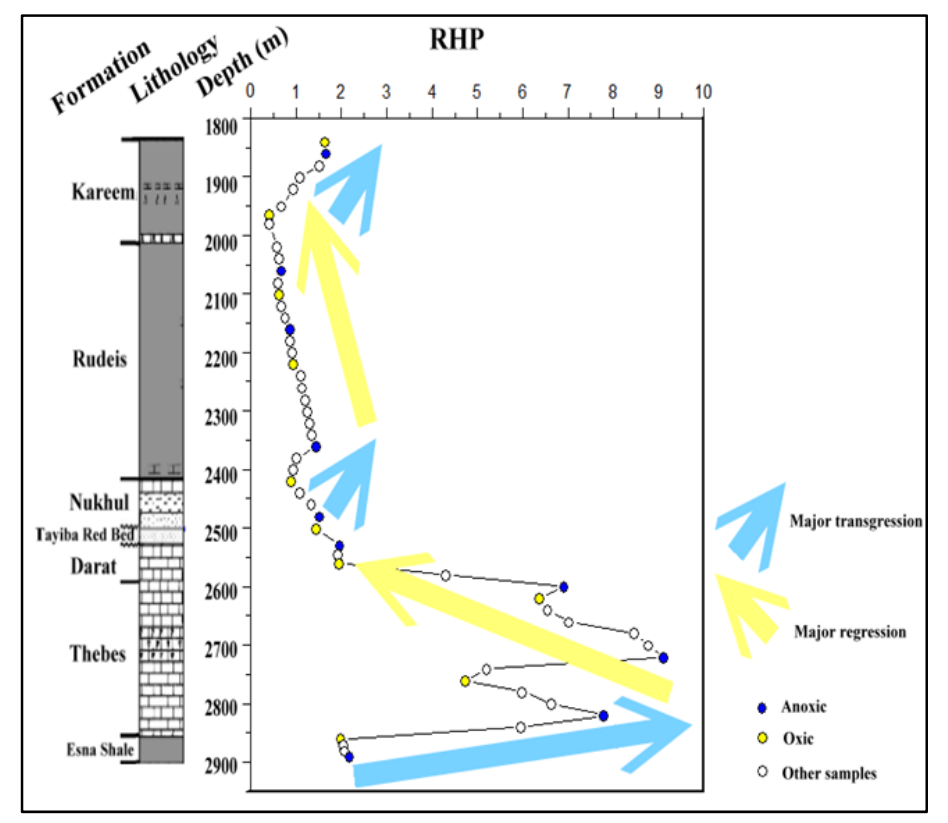

Fig. 11: Transgression-regression mega-cycles of the studied Formations based on a RHP parameter (Fang et al. 1993).

The dogleg shaped of the measured vitrinite reflectance versus the burial depth of the selected sequence within the EE85-1A well give us the ability to separate each zone of data and applied statistical studies to give a linear relationship concerns each part (Fig. 12). By applying a coefficient of the linear regression on the upper sequence (the Kareem, the Rudeis, and the Nukhul Formation) above the depth of $2500 \mathrm{~m}$ shows that the vitrinite reflectance increase slowly by trigger increasing in depth $(n=32, r=0.94$, and $S d=0.006)$. Dissimilarity, the lower part of the Darat, the Thebes, and the Esna Shale Formation displays a rapid increase in vitrinite reflectance with little increase in depth $(\mathrm{n}=22, \mathrm{r}=0.98$, and $\mathrm{Sd}=0.01)$. By drawing lines representing a different maturation zone based on vitrinite reflectance crossing the extended dot lining that was drawn according to the statistical regression relationship of the studied samples, the active oil zones are recognized between $2890 \mathrm{~m}$ and $4450 \mathrm{~m}$.

\section{DISCUSSION AND CONCLUSION}

The selected sedimentary Formations from the well EE85-1A is an important sequence in the Suez Gulf. It includes two mega-sequences from the main fives mega-sequences throughout the Gulf history (Bosworth et al., 1998; Peijs et al, 2012). The third mega-sequence of Pijis et al. (2012) initiated from The Duwi Formation until thevDarat Formation synchronousonset of the Syrian-Arc to the clysmicRift tectonics. The fourth mega-sequence corresponds to the Nukhul, the Rudeis, and the Kareem Formation of the Rift-infill contemporary the proper clysmic rift to the onset of the Dead Sea tectonics (Patton, 1994; Moustafa and Khalil, 1995).

The above-mentioned mega-sequencesare coinciding with the obtained results of the present two mega-cyclesof sea level illustrated by the geochemical parameter of RHP (Fig.11).

The TOC contents of the studied Formation according to the classification of Peters and Casss (1994) show three categories of petroleum potential (Fig. 4). The first is fair related to both the Rudeis and the Esna Shale Formations. The second is good for the Kareem, the Nukhul, and the Darat 
Formations. The Thebes Formation is a very good to excellent. Generally, the high values of TOC can give conformity of either good preservation or high biota and/or flora productivity (Jasper et al., 2010).

Fig. 12. Predicted thermal maturity levels of the studied Formation (Peters and Cassa 1994).

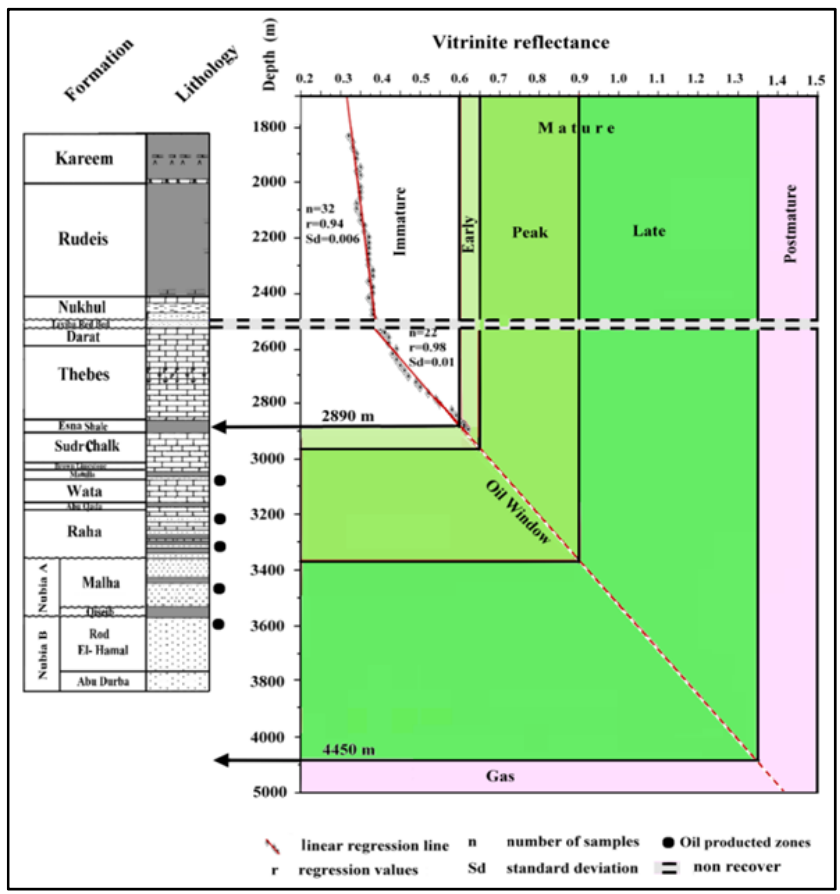

However, the TOC cannot be used as the sole parameter to interpret the OM quantitative due to its contents may be coming from (organic) oxygen, hydrogen, nitrogen, sulfur, etc. (El Atfy et al., 2014). Furthermore, the OM may be subjected to reworking, oxidation or reach to a high post-mature level where exhibit low level of petroleum to be extracted.

So that, both amounts of $\mathrm{S} 1$ and $\mathrm{S} 2$ are almost used to confirm the petroleum potentiality in combined with the previous TOC contents. The amounts of hydrocarbon release at $300^{\circ} \mathrm{C}$ of the pyrolysis (S1) and those came from cracking of kerogen at $\approx 600^{\circ} \mathrm{C}(\mathrm{S} 2)$ denote all sedimentary Formations are of poor potential with the exception of the Thebes Formation of the majority good to excellent potential (Fig. 4).

Additionally, plotted the obtained data of the studied Formations on Py versus TOC diagram established by Ghori and Haines (2007) demonstrate that the petroleum potential of the all Formations within poor to fair zones, whereas, The Thebes Formation displays dominance ( $80 \%$ ) of very good to excellent potential (Fig. 5).

Quality is expressed in the present study by HI and S2/S3 ratio (Peter and Cassa, 1994). The change in the kerogen type can also give a good idea in term of transgression- regression assessments (Habib and Miller, 1989). Omara and Hoyanagi (2004) reported that the transgressive sea suggested by high amounts of HI and low amounts of terrestrial OM (Kerogen III) and increase in aquatic and marine OM of Type I and II. Hart et al. (1994) stated that the increase in the percentages of the Type IV and III in a sedimentary sequence is attributed to the deposition close to the shoreline of dominant regression.

As to plot of study samples on figure seven, according to Peter and Cassa (1994) show the majority of Type IV and III (inert and gas-prone) in all sedimentary Formation excluding the Thebes Formation of type II and I (oil-prone).

Moreover, the values of the S2/S3 ratio of the studied sequence show that the type IV is prevalent in both the lower part of the Kareem Formation and the entire of the Rudeis Formation samples (Fig. 6). The latter observation can point toward either reworking of OM or oxidation by dropping of sea level toward the lower part of the Kareem Formation and deposition of evaporates (anhydrite minerals) that commonly precipitate by decreasing the volume of seawater to reach $70 \%$ water loss in comparison to its original volume, that associate exactly by considerable fall of the sea level (Einsele, 1992). Type III is the dominance in the upper Kareem, the Nukhul, the Darat, and the Esna Shale 


\section{Organic geochemistry of Paleocene - Middle Miocene Succession}

Formations. Again, based on S2/3 ratio the Thebes Formation is the prime quality one in the studied sequence comprises of prevailing Types II and II/III (Fig. 6).

Kerogen type diagram of van-Krevelin (1993) is also used to detect the types of the studied OMbearing the sedimentary Formations. In which, all studied Formation occupies the area of Type III and three samples (K6, K7, and K8) of the lower Kareemoccupy the type IV pathway (Table 1), while the types II and I belong only to the Thebes Formation (Fig. 7).

The aforementioned result reveals that the Thebes Formation is the only of the studied sequence is capable to be the effective source rock of both high TOC and very-good quality of Kerogen Types I and II if it is subjected to the appropriate thermal maturity level.

Unfortunately, the obtained results of the thermal maturity parameters of Tmax, Ro, and PI in the present study show all the studied Formations are immature or marginally early mature in case of the deepest burial depth of The Esna Shale Formation (Figs, 9-10, 12).

The most important conclusion that the promising Thebes Formation cannot be an effective source rock except if it is buried enough to proceed the active, measuredoil-window zone suggested by the present study intervals between 2890 and $4450 \mathrm{~m}$ under a geothermal gradient of $28^{\circ} \mathrm{C} / \mathrm{km}$. Maky et al. (2010) mentioned that the Thebes Formation is one of three considers a very good source rock within the central Gulf area. In his study, the Thebes Formation was founded at great depth intervals between $3716 \mathrm{~m}$ and $3945 \mathrm{~m}$ in the well WFA-1 and between $3109 \mathrm{~m}$ and $3429 \mathrm{~m}$ in the well GS 197-2. From the above-mentioned wells, the Thebes Formation reaches to burial depths enough to subject an appropriate thermal maturity level that suggested in between $2850 \mathrm{~m}$ and $4450 \mathrm{~m}$ depth of the oilwindow potentials in the present study (Fig. 12).

Generally, in the subsurface wells, the relationship between the Ro and depth are characterized by two linear gradient segments connected together by a bending segment. Suggate (1998) stated that the Ro in the lower gradient segment increases more rapidly than within the upper gradient segments.

Consequently, by drawing a dots relationship between the Ro and the depth of the present samples, a two trend of the approximately linear relationship is present above and below a depth of $2500 \mathrm{~m}$ (Fig. 8A). To illustrate the upper and lower linear gradient a statistical regression line is measured by software of Origin Pro (Fig. 12), in which the rate of increasing Ro in the lower linear gradient is six times more than the rate of its increase in the upper linear gradient (Fig. 12). The lower linear gradient is used in the present study by a combination of maturity values according to Peter and Cass (1994) to predict the active mature oil-window interface.It is suggested within the depths of $2890 \mathrm{~m}$ and $4450 \mathrm{~m}$, after that depth a postmature is present. The fifth produced oil reservoirs from the present well are situated within the present study peak and late mature horizons (Fig. 12).

According to Suggate the values of Ro of the present day well are not coinciding with the nowadays measured depths. So that, Suggate (1998) draw a standard diagram to detecting the ancient depth before any missing of strata occur either by erosion from the surface of the studied sequence or by an unconformities in between or within the different studied Formations (Fig. 8B). By transfer, the previous relation between Ro and Depth (Fig. 8A) on the standard diagram of Suggate (Fig. 8B), two important data are revealing. Firstly, the studied sedimentary sequence is located within the geothermal gradient of $28^{\circ} \mathrm{C} / \mathrm{km}$. Secondly, the missing of strata reaches $2090 \mathrm{~m}$, or by another meaning, the ancient burial depths for Ro values of the studied sequence must be higher than the present day depths by adding $2090 \mathrm{~m}$ thickness.

The sea level cycles based on geochemical parameter RHP and HI in the present study have inappropriate with the fact of invasion of the sea overEgypt reached its fairly deep marine during the deposition of Thebes Formation and sea retreat again at the end of Late Eocene (Issawiet al., 1999). The sharp cycle (lower cycle) of the pre-rift strata were started by a high transgression from the end of the Esna Shale Formation to reach its threshold during the middle of the Thebes Formation of prevailing anoxic condition (Fang et al., 1993). After that, the sea retreats again by sharp regression until the end of the Darat Formation (Fig. 11). The second cycle (upper cycle) is a mild one, was started by transgression during the syn-Rift deposition of the Nukhul Formation, then sea retreats again throughout the Rudeis Formation till the Lower Kareem Formation, then the level of sea flooded again during the deposition of the Upper Kareem Formation. 
Khaled, K. A. M. and Edress, N. A. A.

It worth to mention from the present study there is a vital relationship between the type of kerogen and transgression-regression sea level change (Figs. 6 \& 11). The maximum transgression characterized by dominating Type I and II of the Thebes Formation mainly of marine origin and oilprone potential, whereas maximum regression characterized by the dominators of Types IV and III of terrestrial origin and inert to gas-prone potential. The maximum oxic condition in the present sea level cycles associated with the presence of anhydrite streaks minerals that precipitate chemically by a fatal drop of sea level at the lower part of the Kareem Formation.

\section{ACKNOWLEDGMENTS}

The authors give kindly thanks to the (EGPC) Egyptian General Petroleum Company for providing us the cutting samples, the stratigraphic sequence, and well-log chart for the studied well to accomplish this study. Great thanks also to Dr Ivana Sykorova in the IRSM of the Czech Republic for her kindly measurments of the Ro of the studied samples.

\section{REFERENCES}

Abdel Zaher, M.; Saibi, H., ElNouby M.; Ghamry, E.; Ehara, S.(2011): A preliminary regional geothermal assessment of the Gulf of Suez, Egypt. J. Afr. Earth Sci. 60(3), 117-132

Afifi, A. S.; Moustafa, A. R.;Helmy, H. M. (2016): Fault block rotation and footwall erosion in the southern Suez rift: Implications for hydrocarbon exploration. Marine \& Petrol. Geol., 76, 377-396.

Ali, R. and Khairy, A. (1996): EGPC $13^{\text {th }}$ Petroleum Conf., Exploration, Cairo, Egypt 2, 396-409.

Alsharhan, A. S. (2003): Petroleum geology and potential hydrocarbon plays in the Gulf of Suez rift basin, Egypt AAPG, Bull. 87, 143-180.

Alsharhan, A. S.; Salah, M. G. (1995): Geology and hydrocarbon habitat in rift setting: northern and central Gulf of Suez, Egypt. Bulletin of Canadian Petroleum Geology 43(2), 156-176.

Atia, M. H.; Ahmed, A. M.; and Korrat, I. (2015): Thermal Maturation Simulation and Hydrocarbon Generation of the Turonian Wata Formation in Ras Budran Oil Field, Gulf Of Suez, Egypt. Rev. J. Environ. Sci, 44(1), 57-92.

Abu Al-Atta, M.; Issa, G. I.; Ahmed M. A.; Afife, M. M. (2014): Source rock evaluation and organic geochemistry of Belayim Marine Oil Field, Gulf of Suez, Egypt. Egypt. J. Petrol., 23, 285-302

Barker, C. E. (1996): A comparison of vitrinite reflectance measurements made of wholerock and dispersed organic matter concentrate mounts. Organic Geochem. 24, 251-256.

Bosworth, W.; Crevello, P.; Winn Jr. R. D.; Steinmetz, J. (1998): Structure, sedimentation, and basin dynamics during rifting of the Gulf of Suez and north-western Red Sea. In: Purser, B. H.; Bosence, D. W. J. (Eds.), Sedimentation and Tectonicsin Rift Basins: Red Sea Gulf of Aden. Chapman Hall, London, pp. 77-96.

Boukhary, M.; Abd El Naby, A.; Faris, M.; Morsi, A.(2012): Plankton stratigraphy of the Early and Middle Miocene Kareem and Rudeis Formations in the central part of the Gulf of Suez, Egypt. Hist. Biol 24, 49-62.

Chowdhary, L. R. S. and Taha, M. A. (1987): Geology and habitat of oil in Ras Budran field, Gulf of Suez. AAPG Bull. 71, 1274-1293.

Chowdhary, L. R.; Shaheen, S.; Naggar, A. A. (1986): EGPC $8^{\text {th }}$ Exploration Conference, Cairo, Egypt, pp. 308-321.

Darwish, M. and El Araby (1993): Petrography and diagenetic aspects of some siliclastic hydrocarbon reservoir in relation to the rifting of the Gulf of Suez, Egypt. Geol. Soc. Egypt, Spec. Publ. 1, 155187.

Darwish, M.; El Barkooky, N. A.; Tewfik, N.; Hellem, T.; Amundsen, H.(1998): Early Rift facies and tectonics in the Gulf of Suez, Egypt "Nukhul Block" as a case study: AAPG BULL. Hedberg Conference.

Dolson, C. J.; Shaan, V. M.; Matbouly, S.; Harwood, C.; Rashed, R.; Hammouda, H.(2001): The Petroleum Potential of Egypt. In: Downey, W. M.; Threet, C. J.; Morgan, A. W. (Eds.), Petroleum proviences of the twenty-first century. AAPG BULL. Tulsa, Oklahoma. 453-482.

EGPC (Egyptian General Petroleum Corporation) (1996): Gulf of Suez Oil Fields, A Comprehensive Overview. Cairo, Egypt.

Einsele, G. (1992): Sedimentary Basins: Evolution, Facies and Sediment Budget. Springer-Verlag Berlin Heidelberg, Germany. 


\section{Organic geochemistry of Paleocene - Middle Miocene Succession}

El Atfy H.; Brocke, R.; Uhl, D.; Ghassal, B.; Stock, A. T.; Littke, R. (2014):Source rock potential and paleoenvironment of the Miocene Rudeis and Kareem formations, Gulf of Suez, Egypt: An integrated palynofacies and organic geochemical approach. Inter. J. coal geol., 131, 326-343.

El Diasty, W. S.; El Beialy, S. Y.; Abo Ghonaim, A. A.; Mostafa, A. R.; El-Atfy H., (2014): Palynology, palynofacies and petroleum potential of the Upper Cretaceous-Eocene Matulla, Brown Limestone and Thebes formations, Belayim oilfields, central Gulf of Suez, Egypt. J. Afr. Earth Sci., 95, 155-167.

El-Khadragy, A. A.; Shazly, T. F.; Ramadan, M.; El-Sawy M. Z. (2017): Petrophysical investigations to both Rudeis and Kareem formations, Ras Ghara oil field, Gulf of Suez, Egypt. Egypt. J. Petrol., 26, 269-277

El Nady, M. M. (2006): The hydrocarbon potential of Miocene source rocks for oil generation in the South Gulf of Suez. Egypt. J. Pet. Sci. Tech. 24, 309-361.

El Nady, M. M. and Mohamed N. S. (2016):Source rock evaluation for hydrocarbon generation in Halal oilfield, southern Gulf of Suez, Egypt. Egyptian Journal of Petroleum 25, 383-389,

El Nady, M. M.; Harb, F. M.; Mohamed, N. S. (2016): Geochemical characteristics of organic matter from Rudeis and Kareem source rocks, Ras Budran oilfield, central Gulf of Suez, Egypt. Energy sources, Part A: Recovery, utilization, and environmental effect 38(22), 3273-3282

Espitalie, J. M.; Laporte, J. L.; Madec, M.; Marquis, F.; Laplot, P.; Paulet, J.; Boutefeu, A.(1997): Rapid method for source rock characterization, and for determination of their petroleum potential and degree of evolution. Revue de l'Institut Francais du Petrole et Annales des Combustibles Liquids 32, 23-24.

Fang, H.; Jianyu, C.; Yongchuan, S.; Yaozong, L. (1993) Application of organic facies studies to sedimentary basin analysis: a case study from the Yitong Graben, China. Org Geochem. 20, 27-47.

Fowler, M.; Snowdonand, L.; Stasiuk, V. (2005): Applying petroleum geochemistry to hydrocarbon exploration and exploitation, AAPG Short Course Notes, June 18-19, 2005, Calgary, Alberta.

Ghori, K. A. R. and Haines, P.W. (2007): Paleozoic Petroleum Systems of the Canning Basin, Western Australia: A review. Search and Discovery Article \#10120.

Gürgey, K. and Bati, Z. (2018): Palynological and petroleum geochemical assessment of the Lower Oligocene Mezardere Formation, Thrace Basin, NW Turkey. Turkish J. Earth Sci., 27, 349-383.

Henaish, A.(2018): Fault-related domes: Insights from sedimentary outcrops at the northern tip of the Gulf of Suez rift, Egypt. Marine and Petroleum Geology, 91, 202-210.

Hunt, J. M. (1996): Petroleum Geochemistry and Geology $2^{\text {nd }}$ Eds., W. H. Freeman and Company.

ISO 7404/5(2009): Methods for the petrographic analysis of bituminous coal and anthracite. Part 5: Method of determining microscopically the reflectance of vitrinite. International Organization for Standardization. Geneva. Switzerland

Issawi, B.; El Hinnawi, M.; Francis, M.; Mazhar, A.(1999): The Phanerozoic Geology of Egypt: a Geodynamic Approach, vol. 76. Egyptian Geol. Survey Spec Publ. 1-462

Jasper, K.; Hartkopf-Fröder, C.; Flajs, G.; Littke, R. (2010): Evolution of Pennsylvanian (Late Carboniferous) peat swamps of the Ruhr Basin, Germany: comparison of palynological, coal petrographical and organic geochemical data. Inter. J. Coal Geol., 162, 346-365.

Jarvie, D. M.; Morelos, A.; Han, Z. (2001): Detection of pay zones and pay quality. Gulf of Mexico: application of geochemical techniques. Gulf Coast Assoc. Geol. Soc. Transactions. 51, 151-160

Khairy, A. and Swidan, N. (1992): EGPC $11^{\text {th }}$ Exploration and Production Conference, Cairo, Egypt, Exploration. 396-409.

Koeverdon, J. H. V.; Karlsen, D. A.; Backer-Owe (2011): Carboniferous non-marinesource rocks from Spitsbergen and Bajornoya: comparison with westernArctic. J. Petrol. Geol. 34 (1), 53-66.

Lüning, S. (2005): North African Phanerozoic, In:Selly, R. C., Cocks, L. R. M., Plume I. R. (Eds), Encyclopedia of Geology, Elsevier Academic Press, 12-26.

Maky, A. F.; Mousa, A. S.; Mohamad, N. I. (2010): Source rock and paleoenvironmental evaluation of some pre-rift rock units at the central part of the Gulf of Suez, Egypt. J. App. Sci. Res., 6(2), 511-528.

Moustafa, A. R. (2002): Controls on the geometry of transfer zones in the Suez rift and northwest Red Sea: Implications for the structural geometry of rift systems. AAPG, Bull 86, 979-1002.

Moustafa, A. R.; Khalil, M. H. (1995): Superposed deformation in the northern Suez rift, Egypt: relevance to hydrocarbon exploration. J. Petrol. Geol., 18, 245-266. 
Khaled, K. A. M. and Edress, N. A. A.

Nabawy, B. S. and El Sharawy, M. S. (2018):Reservoir assessment and quality discrimination of Kareem Formation using integrated petrophysical data, Southern Gulf of Suez, Egypt. Marine and Petroleum Geology 93, 230-246.

Patton, T. L.; Moustafa, A. R.; Nelson, A. R.; Abdine, A. S. (1994): Tectonic evolution and structural settings of the Gulf of Suez rift. In: M. S. (Eds.) Interior rift basins. London. AAPG BULL. Memoir (59), 9-56

Peijs, J. A. M. M.; Bevan, T. G.; Piombino, J. T. (2012): The Gulf of Suez rift basin, In: Phanerozoic Rift Systems and Sedimentary Basins, Elsevier, pp.165-194.

Peters, K. E., and Cassa, M. R.b (1994): Applied source rock geochemistry. In: Magoonand, L. B., Dow, W. G., (Eds.). The petroleum system from source to trap. AAPG. 93-120.

Rahman, S. A. and Zahran, I. (1986): Contribution of V.S.P. in understanding the structural pattern in Ras Budran area, Gulf of Suez, Egypt. EGPC $8^{\text {th }}$ Exploration Conf., Cairo, Egypt, 2, 417-433.

Rahmani, O.; Aali, J.; Junin, R.; Mohseni, H.; Padmanabhan, E.; Azdarpour, A.; Zarza, S.; Moayyed, M.; Ghazanfari, P. (2013): The origin of oil in the Cretaceous succession from the South Pars Oil Layer of the Persian Gulf. Inter. J. Earth Sci., (Geol Rundsch) 102, 1337-1355

Salah, M. G. (1992): Geochemical Evaluation of the Southern Sector of the Gulf of Suez, $11^{\text {th }}$ EGPC Explor. Semin., Egypt, 383-395.

Schumacher, B. A. (2002): Methods for the determination of total organic carbon (TOC) in soils and sediments. ERASC, Office of Research and Development US. Environ. Protection Agency. 1-25.

Shahin, A. N. (1988): Oil window in the Gulf of Suez. Abs., AAPG, BULL. 72, 1024-1025.

Suggate, P. R. (1998): Relations between depth of burial, vitrinite reflectance and geothermal gradient. J. Petrol. Geol., 21(1), 5-32.

Taylor, G. H.; Teichmuller, M.; Davis, A.; Diessel, C. F. K.; Littke, R.; Robert, P.(1998): Organic petrology, Berlin, Gebruder Borntraeger.

Tissot, B. P. and Welte, D. H. (1984): Petroleum Formation and Occurrence, $2^{\text {nd }}$ ed. Springer, Berlin.

Younes, M. A.(2001):Application of biomarkers and stable carbon isotopes to assess the depositional environment of source rocks and the maturation of crude oils, East Zeit Field, southern Gulf of Suez, Egypt. Petroleum Sci. and Tech., 19, 1039-1061.

Van Krevelen, D. (1993): Coal: Typology, Chemistry, Physics and Constitution. Coal Science and Technology Series3.Elsevier, Amsterdam.

Waples, D. W.(1985): Geochemistry in petroleum exploration. International Human Resources and Development Corporation, Boston.

Zahra, H. S. and Nakhla, A. M. (2015): Deducing the subsurface geological conditions and structural framework of the NE Gulf of Suez area, using 2-D and 3-D seismic data. NRIAG Journal of Astronomy and Geophysics 4, 64-85. 
دراسات جيوكميائية عضوية على التتابعات الترسيبية من عصر الباليوسين الى عصر المايوسين الاوسط

بيئر EE85-1، منطقة رأس بلران ، خليج السويس ، مصر .

خالد أحمد مصطفى خالد و نادر أحمد أحمد إدريس

قسم الجيولوجيا - كلية العلوم - جامعة حلوان

\section{الخلاصة}

تقع منطقة رأس بدران فى الجزء الاوسطى الثرقى بالمياة الضحلة بخليج السويس. ثم اختيار التتابع الرسوبى من عصر الباليوسين الى أسفل عصر المايوسين الاوسط لتقييمه ودراسته فى البئر 1-EE85 بمنطقة رأس بدران. الدراسات

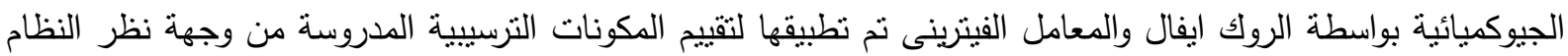
البترولى ـ منها تم تجميع عدد اربعة وخمسون عينة حفر تمنل ستة مكونات صخرية هي مكون أسنا، مكون تيبيس ، مكون دارات ، مكون نخل، مكون روديس، ومكون كريم تتملهم العصور المختارة .

اظهرت الدراسة الحالية ثلاث فئات مختلفة لصخور المصدر على حسب الجهر البترولى. الفئة الاولى وتتشمل مكون تيبيس وهو تم تصنيفه على انه صخر مصدر من النوع الجيد جدا الى الممتاز اعتمادا على ما يحيويه من الكربون

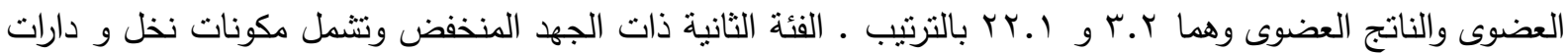

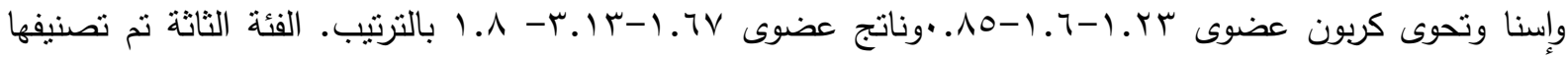
على انها صخر مصدر فقير وتتمل كلا المكونين كريم وروديس بنسبة كربون عضوى ع. 1-90. . وناتج عضوى 1.0

أظهرت الدراسة أن نوع الكيروجين بالمكونات المدروسة يشمل النوع واحد واثثين الذى ينتج الزيت والغاز بمكون تيبيس

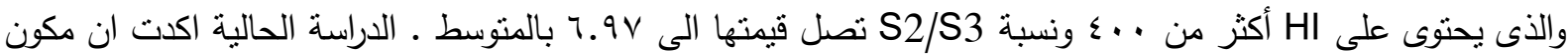
تيبيس هو صخر مصدر ذو تاثير قوى بخليج السويس إذا نم دفنه لعمق أكثر للوصول الى العمق المناسب لنطاق نافذة

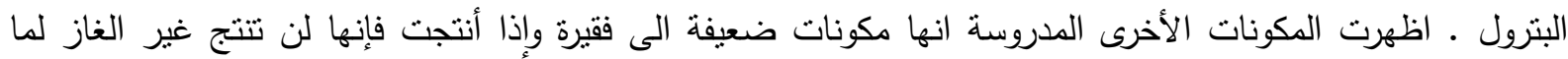

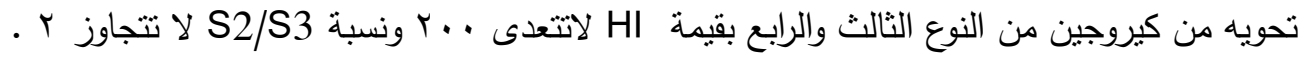
بدراسة المعامل الفيترينى للمكونات المدروسة أتضح أن كل المكونات الرسوبية الددروسة غير ناضجة أو تقع على حافة النضوج حيث انها لم تتجاوز با.... الدراسة الحالية اظهرت نطاقين كبيرين لتذبذب مستوى سطح البحر اعتمادا على

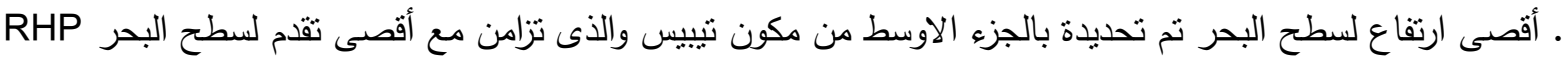
اقليميا . والذى أدى بدورة الى ظروف مواتية لاثراء مكون تنيبيس بالمواد العضوية البحرية اثثاء الترسيب. 

